\title{
Training on Intercultural Communicative Competence in College Japanese Teaching
}

\author{
Tingting $\mathrm{Wu}$ \\ College of Foreign Languages, Bohai University, Jinzhou, 121013, China \\ wtt0527@163.com
}

\begin{abstract}
Keywords: college Japanese teaching; intercultural communicative competence; existing problems; training strategy
\end{abstract}

\begin{abstract}
Training on intercultural communicative competence is mainly to pass on knowledge and train skills, through the ability of the various aspects of knowledge and skills to improve students' intercultural communicative competence. Intercultural communicative competence consists of knowledge factors, affective factors, situational characteristics and mental activity characteristics. At present, there are the problems of the teaching methods of college Japanese teaching, such as the outdated teaching methods, the lack of language practice, the low quality of Japanese teachers and the enlargement of the enrollment scale of universities. Focusing on these issues, puts forward to improve the intercultural communicative competence includes: strengthens into the Japanese society and culture, uses the network resources to feel the real context, improves the comprehensive quality of Japanese teachers, strengthens the cultivation of students' communicative competence, cultivates students' autonomous learning ability and pays attention to the non-language cultural communication.
\end{abstract}

\section{Introduction}

Communication is the process of interaction and exchange of information between people and people, is a continuous process of interaction of multiple elements. Communication is not carried out in a vacuum zone, always carries out in a certain social and cultural environment. Therefore, the communication process and the elements will continue to be affected by the environment and other factors. When the cultural differences between the various elements, it is the intercultural communication. "Intercultural communicative competence" is refers to the communication between native speakers and non-native speakers, also refers to any communication between people with different linguistic and cultural backgrounds. Good interpersonal skills and good interpersonal skills are necessary for the survival and development. Intercultural communicative competence is a kind of communication behavior, on the types of communication, can be interpersonal communication, also can be the communication between individuals and groups. The continuous development of economic globalization and the information network, and the globalization has become an irreversible trend, from different geographical and cultural background of the people being formed in the position of world citizenship survival, intercultural communicative competence becomes people's basic survival skills [1]. How to cultivate and improve students' intercultural communicative competence is not only a subject in the field of international communication and communication, but also an important subject in College English teaching. The traditional teaching of college Japanese ignores the cultivation of intercultural communication competence and ignores the Japanese social and cultural phenomenon and cultural connotation of the excavation, resulting in students setbacks in intercultural communicative competence, brings the misunderstanding or unpleasant to the two sides, the intercultural communication can not be carried out smoothly.

Although the Japanese language system comes from Chinese, but there is a huge difference between the two countries in both language and culture. Therefore, even if the students have a good command of Japanese, it is inevitable that there will be an exchange of obstacles or misunderstanding with the Japanese. The primary task of Japanese teaching is to cultivate students' 
ability to use language. On this basis, it should pay attention to the cultivation of students' intercultural communicative competence. Master a solid language knowledge, but the lack of understanding of Japanese culture, the Japanese habits and the Japanese values, often encounters unnecessary trouble and misunderstanding [2]. For example, the Japanese are very strong time concept, strictly abide by the time of the nation. Although the concept of time in the Chinese people are constantly strengthened, but a few minutes late, in the Chinese people's time concept is acceptable. But in Japanese culture, do not strictly comply with the time, is considered to have no credit, especially in business activities, it is difficult to establish a cooperative relationship with each other. There are many examples of cultural differences between China and Japan. Intercultural communicative competence is the ultimate goal of foreign language education and language education, and the language education should also be a cultural education to a large extent, foreign language teaching needs intercultural communication theoretical guidance, improves the students' understanding of the cultural differences of intuition and sensitivity. Therefore, as a Japanese teacher not only to teach the knowledge of Japanese language, but also pay attention to the teaching of Japanese culture, the Japanese values, as well as the Japanese language habits.

\section{Composition on Intercultural Communicative Competence}

The intercultural communicative competence is composed of the knowledge factor, the emotion factor, the situation characteristic, the mental activity characteristic and so on. The structure model is shown in Figure 1. Among them, the knowledge factor, refers to the communicators should understand the culture communication object, context and the people to the proper behavior requirements information, is communication correctly interpret communication object conveys the verbal and nonverbal information, is the basis for the choice of appropriate communicative behavior. The lack of intercultural communicative competence knowledge, communication will be unable to determine their communicative behaviour in the context of a cultural purpose, if appropriate; affective factors refers to communicators treat from different culture communication object and cross cultural communicative behavior attitude, in the context of intercultural communication, cultural differences bring potential uncertainty. Communication processing pressure and tolerate a stronger ability to vague and intercultural communicative competence in higher; factors of mental activity is the embodiment of knowledge and emotional factors, including verbal and non verbal expression and role play. Verbal expression refers to how individuals use language. Non verbal expressions include body language, time language, color language, space language, auxiliary language, and so on. Role playing is associated with context, refers to communication in the target culture how according to their own identity role appropriate use of verbal and nonverbal symbols; situational characters refers to in a certain period of time all relative or combination of circumstances, including environment, and target culture, whether there is a contact, the people that play role in society there is a social status differences, the third party interference or participation.

\section{Existing Problems on College Japanese Teaching}

At present, Chinese college Japanese teaching has made great progress, but there are still many problems, whether these problems can be solved in time directly affect the reform and development of Japanese language teaching and intercultural communicative competence ability. Major issues include [3-5]:

(1) Teaching method is old and backward. Teaching methods serve the teaching purpose and teaching tasks, teaching methods are the means to complete the teaching activities of teachers and students. At present, college English teaching methods stay in imparting book knowledge to the hand, do not strengthen the cultivation of Japanese students comprehensive quality, lead to some of the students after graduation can not adapt to the needs of the job, which explains the relying solely on classroom indoctrination style of teaching mode, is difficult to adapt to the current practice of Japanese teaching, teaching objectives, methods and plans need timely improved.

(2) Language practice is not enough. Language is created in the labor practice, language learning 
should also rely on practice, language teaching is a kind of practical teaching activities. Traditional classroom teaching can solve the basic problem of language learning, But only through a lot of practice to acquire language ability and skill. The current Japanese language teaching has neglected the language practice activity, the cultivation of students is more suitable for examination oriented education, but the actual language application ability is very poor, can not meet the social needs of Japanese talent.

(3) The quality of Japanese teachers is low. At present, college Japanese teachers quality is not high and the insufficient number of practical problems, a large number of high level talents of Japanese are not willing to engage in the teaching work of college Japanese, existing college teachers of Japanese, on the basis of ability, the development potential exists serious shortage, especially college Japanese teaching can not attract a sufficient number of teachers, this a series of problems in College Japanese teaching level are difficult to be guaranteed, affect college Japanese teaching quality, and then the comprehensive and overall development of Japanese talent are constrained and obstacled.

(4) The expansion of College enrollment. In recent years, China's colleges and universities are expanding enrollment scale, the quality of students has declined. Student's foreign language ability is uneven, especially from remote areas, foreign language level is compared with the students in large cities, there is a big gap in listening, speaking, reading, writing, translation and so on. Also, because the Japanese belongs to small language, like English can't pass the examination after admission according to the results of group teaching. According to the normal teaching plan, it will make the foreign language ability is poor students, can't keep up with the teacher's teaching progress, learning is very difficult.

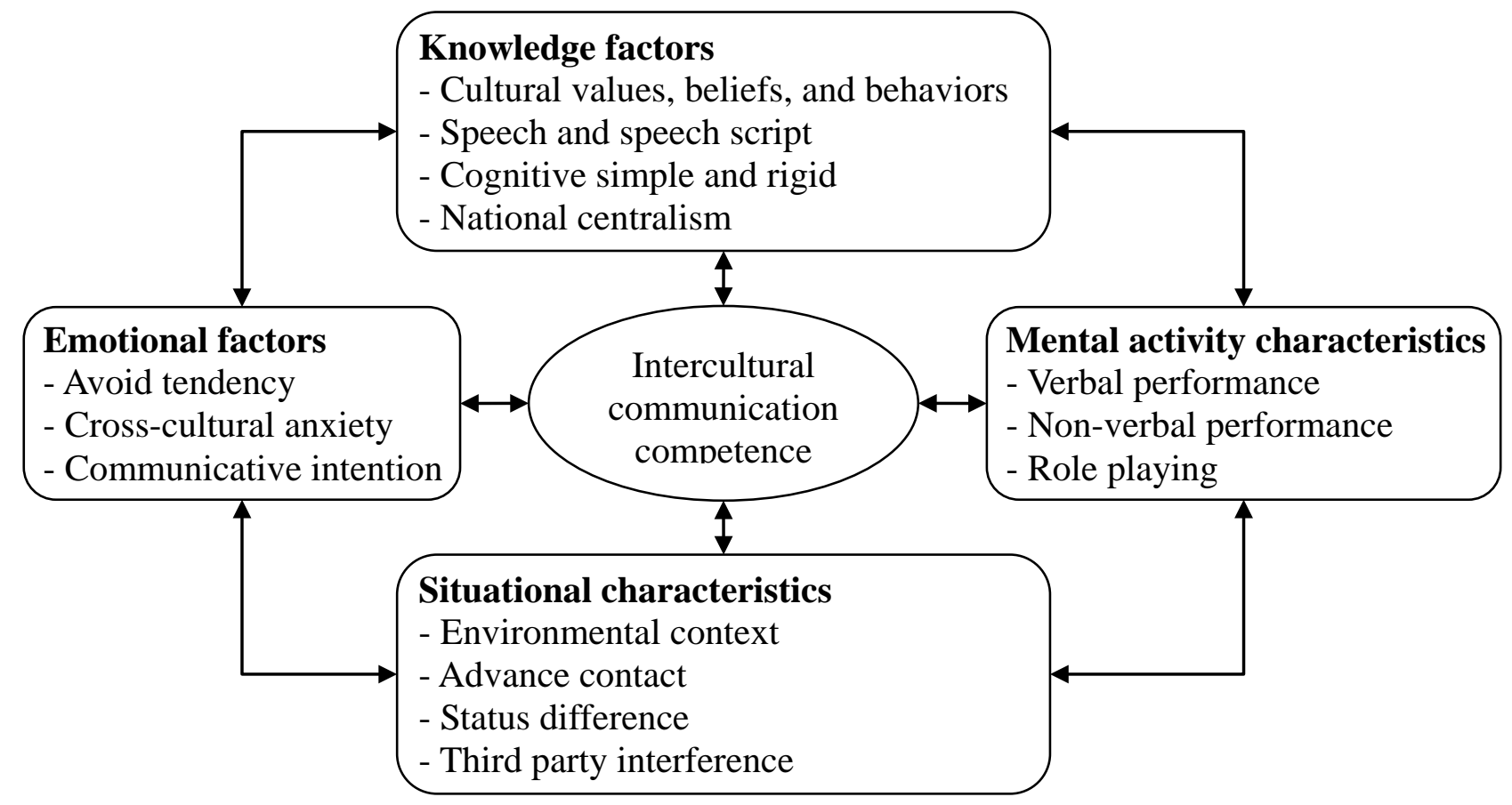

Fig. 1. Structure model on intercultural communication competence

\section{Strategies for Improving Intercultural Communicative Competence}

To achieve intercultural communicative competence ability, need helping students get a lot of cultural content, not only in addition to learning language knowledge, but also have to contact with rich cultural connotation. Teachers should make use of effective teaching methods to infiltrate the cultural elements in the teaching process, students take effective learning methods to take the initiative to absorb the Japanese culture, and finally achieve the goal of enhancing the ability of cross cultural communication. Based on the relevant references [6-10], this paper puts forward the countermeasures to improve intercultural communicative competence: 
(1) Strengthen the introduction of Japanese social culture. Different countries have different language and cultural customs, each language has its own specific social and cultural background. Without understanding the characteristics and changes of social culture, it is not able to understand and use the language correctly. It shoule understand and study the difference between Japanese and Japanese culture in the process of Japanese teaching. Japanese teachers task is not only to teach Japanese language to students, would also like to take various forms to help students understand the Japanese social and cultural knowledge, to train the students not only understand Japanese, but also to understand the situation in Japan, with knowledge of Japanese society, politics, economy and culture, with strong comprehensive application ability of modern applied talents. Improving intercultural communicative competence is the ultimate goal of Japanese language teaching.

(2) Using the network resources to feel the real context. Network environment has created favorable conditions for the cultivation of College Students' intercultural communicative competence. The network not only has language and cultural learning resources, but also a platform for intercultural communicative competence. Network resources include broadcasting, films, TV programs, and electronic media, Japanese website graphicsm which true reflect the social various aspects of the material, make students to stay in a relatively realistic cultural environment, to maximize the feeling real Japanese cultural context and understand Japanese real daily life, the accumulation of Japan cultural background, customs, way of life and social relations of knowledge, improve the ability of cultural understanding. We should Make full use of modern network technology and resources, build a valuable learning environment, promote and support the learning activities of students.

(3) Improving the comprehensive quality of Japanese teachers. Improving Japanese teachers' comprehensive quality is an important factor to strengthen Japanese teaching. Teachers not only need to have skilled Japanese and Japanese thinking, in addition to when necessary using Chinese explanation, try to keep the medium of Japanese habits; also need to continue to strengthen the understanding of Japanese culture, combines the knowledge of written and practical life to explain more students moving image. Teachers as mentors to the process of Japanese students learning, more students into a more broad perspective and Japanese learning experience, which requires teachers timely and students share of existing learning resources, should also be interesting and practical information is introduced into the classroom, carefully designed for each class.

(4) Strengthen the training of students' communicative competence. The ultimate goal of language learning is to develop communicative competence. Communicative competence includes not only the understanding and mastery of the language form, but also the understanding and mastering of the knowledge system in which the language forms are properly used at any time and place. Require teachers in the teaching process, more organization of dialogue practice, set different situations, let the students self expression. Also can use the textbook content to exercise the student's communicative ability, let the students play the role of textbooks to practice dialogue, to further understand the Japanese language and culture. In real life, students can contact with Japanese friends, not only learn the true cultural customs of Japan, but also enhance communicative competence.

(5) Cultivation of students' autonomous learning ability. Autonomous learning is a modern way of learning which is corresponding to the traditional reception learning. Taking students as the subject of study, students themselves are not subject to other people's domination, not by external interference, through reading, listening, research, observation and practice and other means to enable individuals to continue to change the way of behavior. Actively encourage students to participate in the Japanese language training programs offered by the school, and consciously participate in various Japanese communication activities. Make some rules and regulations, encourage and urge students to participate in the second classroom activities, broaden students' vision, cultivate students' autonomous learning ability. Encourage students to participate in the Japanese speech contest, Japanese speech contest, Japanese calligraphy competition, Japanese composition competition, Japanese Translation Contest and the national situation in Japan, such as knowledge competition, and so on. 
(6) Focusing on non language and cultural communication. In intercultural communication activities, in addition to the use of language to communicate, there are eyes, facial expressions and movements, such as a series of non-verbal communication, language communication is a supplement. Different cultures have different non verbal communication. Language communication is very important, but non verbal communication can not be ignored. Cross cultural communication, if you can not properly use non-verbal communication, it is easy to produce unnecessary misunderstanding, affect the communication effect, serious and even lead to the failure of communication. While cultivating students' intercultural communicative competence, teachers should pay attention to the cultivation of non cultural communication and avoid misunderstanding and conflicts in intercultural communication, which can ensure the smooth progress of cross cultural communication.

\section{Conclusion}

Training on intercultural communicative competence in college Japanese teaching is long-term cross disciplines and comprehensive dynamic activities, training effect depends on many factors, both including the education system and social environment and other external factors, also including the concept of teachers and students, teaching materials, the training plan, teaching methods and other internal factors. For teachers, should keep pace with the times in teaching ideas and teaching skills, not only fully equip with the concept that cross culture in Japanese teaching, but also master the outline to develop teaching activities design, update teaching methods, in the process of teaching, cultivate students dimensions of intercultural skills. The design of teaching activities follow from easy to difficult and gradually improve the principle, meet the needs of students; students as the subject of learning, establish a intercultural study consciousness, through more channels to expand the Chinese Japanese cultural knowledge, improve the Chinese Japanese culture expression ability; give some guidance from the teaching syllabus and textbook compilation. Only these internal and external factors act at the same time, intercultural foreign language teaching and students' intercultural communicative competence training can be implemented.

\section{References}

[1] NAREN Tuya, "On the Development of Japanese Learners' Inter-cultural Communication Competence in Higher Education," Foreign Language and Literature Research, vol. 2, no. 2, pp. 93-97, 2016.

[2] C. H. Pu, "How to cultivate intercultural communicative competence in basic Japanese Teaching," Journal of Heilongjiang College of Education, vol. 34, no. 3, pp. 66-67, 2015.

[3] X. L. Guan, "The problem of culture introduction in Japanese Teaching," China Adult Education, vol. 16, no. 1, pp. 183-184, 2008.

[4] Y. Xu, J. X. Huang, "Problems and Countermeasures in Japanese Teaching in China," Journal of Lanzhou Institute of Education, vol. 30, no. 1, pp. 47-48, 2014.

[5] M. Hong, "The Problems and Countermeasures of College Japanese Teaching," Heilongjiang Science, vol. 6, no. 8, pp. 105-106, 2015.

[6] H. Y. Yang, M. L. Bian, X. M. Cong, "Research and Practice on the reform of the teaching mode of Japanese courses in Universities," Journal of Inner Mongolia University of Technology (Social Sciences Edition), vol. 23, no. 1, pp. 121-124, 2014.

[7] Q. Chen, "Analysis on the measures of cultivating intercultural communicative competence in the course of Japanese language education," World Latest Medicine Information, vol. 16, no. 22, pp. 202-203, 2016. 
[8] X. Pei, "A study on the training system of cross cultural communication ability of Japanese major students," Journal of Heilongjiang College of Education, vol. 35, no. 6, pp. 144-147, 2016.

[9] X. B. Zhou, "A study on the strategies of cultivating intercultural communicative competence in college Japanese teaching," Journal of Xuchang University, vol. 35, no. 1, pp. 147-148, 2016.

[10] J. Qu, "Cultivation of intercultural communicative competence in Japanese Teaching," Journal of Educational Institute of Jilin Province, vol. 32, no. 1, pp. 53-55, 2016. 